\title{
ІНТЕНСИВНІСТЬ ВИЯВУ ПОЗИТИВНИХ ЕМОЦЙ У ФРАЗЕОЛОГІЗМАХ АНГЛІЙСЬКОЇ, НІМЕЦЬКОЇ, РОСІЙСЬКОЇ ТА УКРАЇНСЬКОЇ МОВ
}

Стаття присвячена семантичному аналізу фразеологізмів, що позначають інтенсивний вияв позитивних емоцій в англійській, німецькій, російській та українській мовах. У роботі розглянуто засоби вияву інтенсивності позитивних емоцій. Встановлено, що у фразеологізмах зіставлюваних мов найчастіше виявляються емоції радості, захоплення. Для встановлення універсальних і специфічних образних складових у фразеологізмах англійської, німецької, російської та української мов використовуються метафоричні моделі, які дають змогу експлікувати внутрішню форму фразеологізму.

Ключові слова: інтенсивність, експліцитні й імпліцитні засоби вияву інтенсивності, емоція, внутрішня форма, метафорична модель.

Д. Е. ИГНАТЕНКО. ИНТЕНСИВНОСТЬ ВЫРАЖЕНИЯ ПОЛОЖИТЕЛЬНЫХ ЭМОЦИЙ ВО ФРАЗЕОЛОГИЗМАХ АНГЛИЙСКОГО, НЕМЕЦКОГО, РУССКОГО И УКРАИНСКОГО ЯЗЫКОВ

Статья посвящена семантическому анализу фразеологизмов, обозначающих интенсивное проявление положительных эмоций в английском, немецком, русском и украинском языках. В работе рассматриваются средства выражения интенсивности положительных эмоций. Установлено, что во фразеологизмах сопоставляемых языков чаще всего выражаются эмоции радости, восторга. Для установления универсальных и специфических образных составляющих во фразеологизмах английского, немецкого, русского и украинского языков используются метафорические модели, позволяющие эксплицировать внутреннюю форму фразеологизма.

Ключевые слова: интенсивность, внутренняя форма, метафорическая модель, эксплицитные и имплицитные средства выражения интенсивности, эмоция.

1. Природа емоцій та особливості їхньої вербалізації постійно цікавили психологів і лінгвістів (Изард, 1980; Шаховский, 2008; Экман, 2010; Diller, 1992; Nöth, 1992; Wierzbicka, 1999, 1990). Ця увага зумовлена тим, що емоції певною мірою виявляються в усіх сферах діяльності людини, зокрема і мовній. «Емоції необхідні людині для виживання і щастя. Не маючи емоцій, тобто не вміючи відчувати радість і смуток, гнів і провину, ми не були б повною мірою людьми» (Изард 1980: 20).

Емоції виникли в результаті еволюції людини для ii кращої адаптації у навколишньому середовищі. Будь-яку активність людини супроводжують емоційні переживання, завдяки яким вона може відчувати стан іншої людини, співпереживати їй. Психологи виділяють т.зв. базові емоції, тобто основоположні, ті, які не були сформовані в процесі культурного розвитку. Такі емоції мають універсальний характер, оскільки супроводжуються певними реакціями організму, які мають фізіологічний, а не культурно-національний характер. 
Слід зауважити, що психологи не мають єдиної думки щодо кількості базових емоцій. За К. Ізардом існує одинадцять фундаментальних емоцій: радість, здивування, печаль, гнів, відраза, презирство, горе-страждання, сором, інтерес-хвилювання, провина, збентеження (Изард 1980: 176). Натомість П. Екман відносить до базових лише шість емоцій: гнів, страх, смуток, щастя, відраза і здивування (Экман 2010: 48).

Виявити національну специфіку інтерпретації кожної емоції можна лише 3 опертям на універсальні риси їхнього виникнення і перебігу. Як стверджує М. К. Голованівська, емоції практично ніколи не виражаються прямо, а лише через уподібнення до чогось (Голованівська 2009: 310). Вивчаючи проблему категоризації емоцій у лексико-семантичній системі англійської мови, В. І. Шаховський зауважує, що «...емоції, які є частиною природнього розвитку людської раси, є універсальними, їх можна впізнати в усіх культурах», однак «... усі емоції конституюються соціокультурними параметрами, тому, крім універсальних емоційних переживань, наявні і специфічні для певної культури емоції» (Шаховский 2008: 17).

Виступаючи носіями образного значення фразеологізми, що позначають інтенсивність певних емоційних станів, повною мірою виражають специфіку національного сприйняття і пізнання реальної дійсності різними мовними соціумами. Виявлення лінгвокультурної специфіки у способах вираження емоцій, зокрема i позитивних, фразеологізмами у різноструктурних мовах на сьогодні є актуальним. Останнім часом вивчення емоцій все частіше проводиться в межах когнітивних досліджень. Розробці когнітивних сценаріїв емоцій присвячені праці А. Вежбицької. Такі сценарії ідентифікуються за допомогою лексичних універсалій, що дозволяє вивчати людські емоції як універсальні явища, що не залежать від конкретної мови. Когнітивні сценарії використовуються А. Вежбицькою перш за все для опису різних емоційних концептів (Вежбицкая 2011: 209).

У статті розглядається семантика фразеологічних одиниць (далі - ФО), що виражають інтенсивність позитивного емоційного стану суб'єкта у різноструктурних мовах: англійській, німецькій, російській, українській.

Мета роботи полягає у виявленні семантичних особливостей ФО, що характеризують позитивний емоційний стан у зіставлюваних мовах. Для досягнення поставленої мети необхідно вирішити такі завдання: 1) визначити корпус ФО, що позначають інтенсивність позитивного емоційного стану в англійській, німецькій, російській, українській мовах; 2) виявити специфіку актуалізації категорії 
інтенсивності і охарактеризувати експліцитні та імпліцитні засоби іiі вираження у досліджуваних ФО; 3) встановити і описати універсальні та специфічні метафоричні моделі аналізованих ФО у зіставлюваних мовах.

Матеріал дослідження становлять 202 ФО (англ. - 64, нім. - 63, рос. - 38, укр. 37), вилучені методом суцільної вибірки 3 одно- та двомовних фразеологічних словників англійської, німецької, російської та української мов.

2. Поняття «емоція»є складним і багатогранним, воно ще й досі не має чіткого визначення. К. Ізард визначає емоції як щось таке, що переживається як почуття (feeling), яке мотивує, організовує і скеровує сприйняття, мислення і дії» (Изард 1980: 32); На думку П. Екмана, емоція - це процес, особливий тип автоматичної оцінки, що відображає наше еволюційне й індивідуальне минуле (Экман 2010: 16).

Лінгвістичне вивчення емоцій спирається на психологічну основу. Врахування психологічних особливостей і критеріїв виокремлення та розмежування різних емоцій допомагає описати специфіку вираження їх у мові. Враховуючи конструктивність чи деструктивність певної емоції для психіки людини і ії оточення, людські емоції та емоційні стани психологи поділяють на позитивні й негативні (Schwarz, Bless, 1991).

Група ФО на позначення інтенсивності позитивного емоційного стану є значно меншою у кількісному відношенні (202 ФО) порівняно 3 фразеологізмами, що позначають негативний емоційний стан суб'єкта-істоти (649 ФО). У зв'язку з цим правомірним $\epsilon$ твердження В. І. Шаховського: «В усіх мовах емотивів 3 негативною оцінною семантикою у кількісному відношенні більше, ніж емотивів 3 позитивною оцінкою. Позитивні емоції виражаються усіма народами більш одноманітно і дифузно, ніж негативні, які завжди конкретні, чіткі і різноманітні» (Шаховский 2008: 19).

Аналізовані одиниці виражають емоції радості, щастя, захоплення, любові, задоволення та ін.

В аналізованих ФО інтенсивність може виражатися експліцитно та імпліцитно. Експліцитна фразеологічна інтенсивність репрезентується різнорівневими мовними засобами - словотворчими, лексико-граматичними, синтаксичними та ін. Імпліцитна фразеологічна інтенсивність охоплює зону словникових тлумачень як ФО в цілому, так i окремих іiі компонентів, а також зумовлена іiі внутрішньою формою, образною складовою. Поняття внутрішньої форми є досить складним і пов'язане $з$ образністю ФО, а образ найчастіше спирається на реалії, відомі тільки певному народові. Як стверджує Д. О. Добровольський, образність ідіом не має якісних відмінностей від 
образності слів у метафоричному вживанні, йдеться скоріше про кількісні відмінності для більшості ідіом образність є конститутивною ознакою (Баранов, Добровольский 2008: 123).

Отже, внутрішня форма виникає в результаті складної взаємодії вільного словосполучення та переосмисленого на його основі фразеологізму. Засобом актуалізації такого образу найчастіше виступає метафора або метонімія. Тому для експлікації внутрішньої форми фразеологізму створюються метафоричні моделі, які дозволяють виокремити образну складову ФО. Виокремлення тих чи інших метафоричних моделей дає підстави говорити про універсальність або специфічність образних складових у зіставлюваних мовах.

3. Як свідчить матеріал дослідження, у слов'янських мовах кількість фразеологізмів, що позначають інтенсивність позитивного емоційного стану вдвічі менша, ніж у германських. Це, зокрема, можна пояснити екстралінгвальними причинами, зокрема менталітетом народів, мови яких досліджуються, а саме оптимістичністю англійців і німців (ширше - західноєвропейських народів), і більшою схильністю українців та росіян зосереджуватися на негативних аспектах свого життя.

Аналіз ФО з семантикою інтенсивного позитивного емоційного стану дозволив виділити ряд метафоричних моделей (далі - ММ).

3.1. Універсальною, зафіксованою в усіх зіставлюваних мовах, є ММ «сильна радість / захоплення - повітря / небо / верх». У таких фразеологізмах відбувається протиставлення низу (землі) і верху (неба) і відображається уявлення про те, що позитивні почуття ніби підносять людину над земним, буденним і низьким, окрилюють iii, пор.: англ. walk / float on air «feel elated〉 (ODI: 5)`відчувати себе окриленим, бути у піднесеному настрої’, букв. 'ходити / плавати в повітрі'; нім. den Himmel offen sehen «sehr glücklich sein, sich am Ziel seiner Wünsche glauben〉 (Duden: 362)`бути дуже щасливим, вірити у виповнення своїх бажань', букв. 'побачити небеса відкритими'; рос. быть на верху блаженства 〈безгранично счастливым, глубоко удовлетворенным быть, чувствовать себя〉 (ФСРЯ: 61)‘почуватися безмежно щасливим, глибоко задоволеним'; укр. не чути землі під ногами «бути енергійним, рухливим під впливом радісного збудження або хвилювання> (Ужченко: 62).

Верх (небо) в релігійному світосприйнятті пов'язується з раєм, Богом, ангелами, i, відповідно, з такими позитивними емоціями, як щастя, блаженство. В усіх мовах виявлено фразеологізми, які мають біблійне походження і позначають стан безмежного 
щастя блажентсва, напр., англ. in seventh heaven (ODI: 141), нiм. im siebten Himmel sein (Duden: 363), рос. быть на седьмом небе (ФСРЯ: 271-272), укр. почуватися на сьомому небі (Ужченко: 117-118). За давніми іудейськими і мусульманськими віруваннями існує сім небес, на сьомому, найвищому, живе Бог з ангелами, і саме на ньому можна перебувати у стані вічного блаженства. У міфологіях і віруваннях різних народів число «сім» має свою символіку. Сім - число всесвіту, макрокосму, воно означає повноту і сукупність. Сім містить у собі трійку як символ Неба і душі та четвірку як символ Землі і тіла, а тому є першим числом, що охоплює духовне й тілесне (164: 378). У фразеологізмах англійської мови число «сім» може замінюватися числом «дев’ять», а в українській - «десять», що символізує досконалість, напр., англ. on cloud nine sextremely happy> (CCID: 75)“надзвичайно щасливий’, букв. 'на дев’ятій хмарі'; укр. перебувати на десятому небі ґбути дуже задоволеним, радісним, безмежно щасливим> (Ужченко: с. 117-118). Використання цих чисел може мати релігійне та наукове пояснення. Число «дев’ять» $є$ похідним від числа «три» в квадраті, яке символізує триєдність людської природи і відповідно триєдність Всесвіту. Саме число «три» згадується в Біблії. Поділ раю на дев'ять сфер після яких знаходиться Емпірей місце, де перебувають душі блаженних, зустрічаємо, наприклад, у Данте в «Божественній комедії». Наукове пояснення пов'язане з твердженням метеорологів про те, що густі, щільні хмари піднімаються на висоту вісьми миль. Відповідно, перебування на дев'ятій хмарі, яка знаходиться вище, викликає стан легкості і блаженства.

3.2. Велика радість, захоплення може мислитися як певний заповнений простір, ємність, напр., англ. full of beans «be happy, excited and full of energy» (CCID: 2324)‘бути щасливим, схвильованим, повним енергії', букв. 'повний бобів (квасолі)'. У німецькій мові надзвичайно велика радість асоціюється з виходом за чітко окреслені просторові межі, пор.: нім. aus dem Häuschen geraten / sein «(vor freudiger Erregung) außer sich geraten / sein` (Duden: 342)‘(про радісне хвилювання) вийти з себе (втратити самоконтроль)', букв. 'виходити з будиночка, бути поза будиночком', наприклад, Sie sei aus dem Häuschen vor Begeisterung 'Вона не тямила себе від захвату'. Проте цей фразеологізм може характеризувати й негативні емоції, пор.: Heute abend sprichst du besser nicht mit Vater über die Angelegenheit. - Warum nicht? - Er ist völlig aus dem Häuschen. - Was ist denn passiert? - Der Paul ist im Examen durchgefallen 'Сьогодні 
ввечері ти краще не говори з батьком про справу. - Чому? - Він не тямить себе. - Що трапилось? - Пауль провалився на екзамені' (Schemann: 280).

Зауважимо, що в російській та українській мовах вихід за межі певного тілесного простору, який асоціюється із врівноваженістю, спокоєм, характеризує не радість, а гнів, злість, пор. рос. быть не в себе 〈быть в сильном душевном расстройстве〉 (ФСРЯ: 417)‘мати сильний душевний розлад’, быть вне себя хбыть в крайне возбужденном или раздраженном состоянии〉 (ФСРЯ: 418)‘бути в надзвичайно збудженому чи роздратованому стані', напр.: Не обращайте на нее внимания: это она так, не в себе немножко. Немиы ее напугали (Полевой: 223)‘Не звертайте на неї уваги, це вона так, трохи себе не тямить. Німці їі налякали'; укр. виходити з себе «перебувати в стані сильного роздратування, нервового збудження; втрачати спокій, самовладання, терпіння> (СФУМ: 92). Натомість такі фразеологізми як рос. бить (переливаться) через край, укр. бити через край уживаються на позначення саме позитивних емоцій, які переповнюють людину і не можуть замкнутися в обмеженому просторі, а дієслівні компоненти переливаться, бити сигналізують про невичерпність таких позитивних емоцій.

3.3. ФСГ на позначення інтенсивності позитивного психо-емоційного стану включає фразеологізми, в яких людина, яка перебуває в надзвичайно збудженому стані радості, захоплення, порівнюється з твариною / птахом, що перебуває у подібному стані. На цій підставі виділено ММ «надзвичайно щзслива, радісна людина - тварина / nmax». За основу порівняння у таких фразеологізмах можуть братися як змінні стани тварин чи птахів, так і незмінні, іманентні властивості, якими вирізняються ці істоти. Так, у німецькій мові людина, яка сильно радіє, порівнюється 3 кропивником, невеличкою пташкою, яка має гучний голос і гарний своєрідний спів, напр., sich freuen wie ein Schneekönig (Duden: 244), букв. 'радіти як кропивник'. У східносередньонімецьких діалектах Schneekönig (кропивник) - птах, який дуже гарно співає, нагадуючи солов'я. Ця пташка $є$ дуже розповсюдженою у Німеччині, що знаходить підтвердження у наявності в сучасній німецькій мові більше 400 діалектних синонімів кропивника, чимало з яких пов’язані зі словом «цар», пор. подібну ФО sich freuen wie ein Zaunkönig (Duden: 244), букв. 'радіти як кропивник на паркані'.

На відміну від німецької, в російській та українській мовах надзвичайний стан радісного піднесення, збудження не викликає прямих асоціацій з конкретним птахом, а співвідноситься з ними опосередковано, за їхньою головною властивістю - здатністю 
літати, а точніше, з основним засобом, за допомогою якого ця здатність реалізується крилами, пор. рос. летать на крыльях «быть в приподнятом, восторженном настроении> (Федоров: 343)‘бути в піднесеному стані, у захваті’; укр. чути крила за плечима 〈бути сповненим натхнення, душевного піднесення, сили і т. ін.〉 (СФУМ: 773), ростуть крила 〈хто-небудь перебуває у стані піднесення, відчуває прилив сили, енергії, натхнення> (СФУМ: 313).

В українській мові людина в радісному збудженому стані може також уподібнюватись до тварини, зокрема до копитної, яка однак, бриканням, може демонструвати саме своє невдоволення, а не радісні відчуття, напр., вибрикувати гопки 〈дуже радіти〉 (СФУМ: 63)(вибрикувати «раз у раз брикати, стрибати, відкидаючи задні ноги (про копитних тварин)> (СУМ, I: 357)). У німецькій мові виокремлено ФО 3 подібним значенням, пор. das Kalb machen (швейцар. діал.) ‘ausgelassen sein, sich nährich gebärden> (Duden: 398)‘бути невгамовним (дати волю своїм почуттям), смішно поводитися (жестикулювати)', букв. 'робити (вдавати) теля, поводитися як теля', проте у ній акцентується саме на поведінці дитинчати, яке пустує, бавиться.

Широкий ряд асоціацій щасливої, радісної людини 3 тваринами виникає в англійській мові, однак до уваги тут береться найчастіше поведінка тварин у певних ситуаціях, напр.:

like pigs in shit (very pleased and happy because something good has happened) (ODI: 41)‘дуже задоволений і щасливий через те, що трапилося щось гарне', букв. 'як свині у багні' (у багатьох культурах свиня символізує розбещеність і нечистоту (164: 293));

be as happy as a clam (at high tide) «to be very happy and to have no worries (360: 177) буути дуже щасливим і не мати жодних клопотів', букв. 'щасливий як двостулковий молюск (під час приливу)' (молюски відкриваються і стають схожими на посмішку під час приливу, знаходяться у безпеці від хижаків; для них це найщасливіший час);

like a dog with two tails svery pleased and happy because something good has happened> (ODI: 41)‘дуже задоволений і щасливий через те, що трапилося щось гарне', букв. 'як пес з двома хвостами' (відомо, що собаки виражають свою прихильність або радість за допомогою хвоста, яким активно крутять 3 боку в бік, а в цьому фразеологізмі виявляється настільки велика радість, що собаці було б недостатньо й одного хвоста для того, щоб її показати); 
like the cat that got the cream «very proud or pleased because of something you have achieved or got> (LED) ‘ бути гордим (самовдоволеним) або задоволеним через те, що щось дістав або здобув', букв. 'як кіт, який здобув вершки';

(as) happy as a possum up a gum-tree (австрал.) (Кунин: 596), букв. 'щасливий як опосум на евкаліптовому дереві', тобто надзвичайно щасливий, радий.

3.4. Інтенсивний вияв радісних почуттів у фразеологізмах може співвідноситись i зі станами людей, зумовленими їхнім віком (зазвичай, молодим) або соціальним становищем. На цій підставі виокремлено ММ «людина, яка сильно радіє - людина певного соціального стану або віку». Ця модель реалізується лише в германських мовах і представлена в них у вигляді компаративних сполук. Так, у ФО англійської мови почуватися щасливими, радісними можуть представники двох діаметрально протилежних суспільних прошарків - король і розвізник піску, пор.: as happy as a king 〈completely or extremely happy etc〉 (ODEI: 22)'абсолютно або повністю щасливий', букв. 'щасливий як король'; as happy as a sandboy «completely or extremely happy etc〉 'абсолютно або повністю щасливий', букв. 'щасливий як розвізник піску’ (слово ‘boy' вживалося на означення осіб чоловічої статі, які належали до нижчих верств суспільства, так виражалося зневажливе ставлення до них). У XVIII-XIX ст. чоловіки розвозили пісок у палаци вельмож і королів і коли їм щастило скуштувати щось смачне або їх пригощали якимись вишуканими стравами, вони були надзвичайно щасливі. У німецькій мові акцентується увага на віці людини, яка може почуватися надзвичайно щасливою, напр. sich freuen wie ein Stint (північнонім.) 〈sich sehr freuen〉(Duden: 243244)‘дуже радіти', букв. 'радіти як молодик'. Словом Stint 'молодик' у північнонімецькому регіоні називають молодих людей, найчастіше неповнолітню молодь, безтурботну і веселу.

Культурно-національною специфікою відзначається й англ. фразеологізм as happy as a Larry (австрал.) 〈completely or extremely happy etc〉 (ODEI: 22)‘абсолютно або повністю щасливий', букв. 'щасливий як Ларрі', у якому інтенсивний вияв позитивного емоційного стану пов'язаний з конкретною історичною особистістю австралійським боксером Ларрі Фолі (1847-1917). Закінчивши у 32 роки свою успішну кар'єру, він отримав за свій останній бій тисячу доларів і був дуже щасливий. Те, що матеріальні блага викликають відчуття надзвичайного щастя, відбилося i в англійському фразеологізмі feel like a million dollars «feel very healthy and happy) 
(CCID: 106)‘почуватися дуже здоровим та щасливим', букв. 'почуватися на мільйон доларів’.

Крім особових імен реальних людей, у ФО можуть уживатися й імена персонажів літературних і фольклорних творів. Так, в англійській мові виокремлено фразеологізм (as) pleased as Punch «elated or delighted on account of sth (be, look, sound)> (ODI: 26) `у піднесеному настрої або задоволений (радісний) через щось', букв. ‘задоволений як Панч’, де Панч (Punch скорочено від Puncinello) - традиційний персонаж англійського лялькового театру, який традиційно виступав у ролі блазня, гульвіси, веселуна. Панч подібний до російського лялькового героя Петрушки, який, однак, не увійшов до фразеологічного фонду з подібним значенням. У німецькій мові веселощі також можуть пов'язуватися 3 ляльковим театром, однак не 3 якимось одним iii персонажем, а з ляльками загалом, пор. нім. die Puppe tanzen lassen ssehr ausgelassen sein, es hoch hergehen lassen〉(Duden: 600)`бути веселим’, букв. 'Змушувати ляльок танцювати'.

3.5. Почуття радості викликає в людини не лише емоційне збудження, а й прилив фізичної енергії, яка може виражатися в уривчасних швидких рухах, ударах, танку. На цій підставі виокремлено ММ «радість - різкі швидкі рухи / танок», яка реалізується в усіх досліджуваних мовах, пор. англ. strike it lucky «to be very lucky, especially when you were not expecting to> (LED)`бути дуже щасливим особливо тоді, коли ти цього не очікуєш', букв. 'радісно вдаряти' ; нім. auf den Putz hauen sausgelassen sein, feiern〉 (Duden: 600) 'радіти, святкувати', букв. 'бити штукатурку', einen (wilden) Freudentanz aufführen «sich unbändig freuen〉 (Duden: 243)‘шалено радіти’, букв. ‘справжній / шалений танець радості виконувати' (пор. укр. вибрикувати гопки «дуже радіти〉 (СФУМ: 63)); рос. подпрыгивать до потолка くочень сильно радоваться кому-, чему-либо> (Федоров: 486) 'дуже сильно радіти кому-, чому-небудь'; укр. в ударі (бути, перебувати) «в стані душевного піднесення, натхнення; у піднесеному настрої〉 (СФУМ: 733).

3.6. У ФО української та російської мов реалізується уявлення про те, що почуття надзвичайної радості, захвату впливають на здатність людини раціонально мислити, точніше позбавляють ії такої здатності. На цій основі виділено ММ «сильна радість - втрата людиною інтелектуально-вольового контролю над собою». Зазвичай у фразеологізмах акцентується увага саме на неспроможності людини контролювати свої дії і вчинки через сильні емоції. В аналізованих одиницях така втрата 
самоконтролю може виражатися двома способами: 1) використанням імеників і дієслів, пов’язаних з інтелектуально-вольовою діяльністю людини, її здатністю мислити, напр., рос. без памяти веселиться 〈очень сильно веселиться〉 (БФСРЯ: 32.)‘дуже сильно веселитися', себя не сльшшать от радости, застар. 〈полностью отдаваться радости, восторгу> (Федоров: 631)‘повністю віддаватися радості, захвату’; укр. не чути себе 〈бути у надзвичайно піднесеному стані〉 (СФУМ: 772); 2) використанням іменників душа, серце (які ніби є вмістилищем почуттів людини) у незвичній сполучуваності 3 дієсловами фізіологічного стану, напр., рос. сердие замирает «кто-либо испытывает блаженство, умиротворение, чувтво радости〉 (Федоров: 610)'хто-н. відчуває блаженство, заспокоєння, радість'; щземить серие «хто-небудь відчуває піднесення, має добрий настрій> (СФУМ: 642), або з дієсловами звучання, напр., укр. душа (серие) cniває 〈хто-небудь перебуває у доброму, піднесеному настрої, радіє) (СФУМ: 228).

Подібні способи вияву має і почуття сильної любові. Такі одиниці були виокремлені в усіх аналізованих мовах, проте їхня кількість є незначною (англ. - 4, нім. - 2, рос. - 6, укр.- 4). Інтенсивність вияву цього почуття переосмислюється у фразеологізмах через його результат, часто негативний (втрата свідомості, самовладання, божевілля та ін.), пор.: англ. be nutty about somebody/something «to like someone or something very much> (ODI: 205) ‘хто-н. або що-н сильно подобається’, букв. ‘бути схибленим (на чому-небудь); до краю захопленим (ким-небудь)'; рос. $\underline{\partial o}$ безумия любить 〈очень сильно, беспредельно, безгранично〉 (ФСРЯ: 34)‘дуже сильно, безмежно'; укр. $\underline{\partial o}$ нестями (закохатися) 〈дуже, надзвичайно сильно〉 (СФУМ: 434). У слов'янських мовах таке осмислення сильної любові виражається у фразеологізмах, побудованих за прийменниково-іменниковою моделлю, в яких іменник виражає ніби результат (рос. безумие, укр. нестяма), а прийменник до вказує на граничність сили цього почуття.

Символом зосередження сильних емоційних переживань, почуттів, зокрема й кохання, також є серце, а в російській та українській мовах ще й душа (за біблійними уявленнями, серце виражає внутрішню сутність людини (47: 241)). Так, для вираження сили свого кохання, інтенсивності почуття, яке переживає людина, вона може пожертвувати серцем, напр., англ. lose your heart to sb (literary) sto fall in love with someone> (360: 185) 'закохатися’, букв. 'поступатися своїм серцем на користь кого-н. / віддавати своє серце комусь’; нім. jmdm sein Herz schenken «Liebe / tiefe Zuneigung zu jemandem empfinden; sich verlieben; verliebt sein` (RI)‘відчувати до когось кохання, 
глибоку симпатію; закохатися, бути закоханим', букв. 'подарувати кому-н. своє серце'. Також на серце метафорично можуть переноситися властивості істот, а тому воно може тьохкати, співати або ж зазнавати різних ушкоджень, пор.: нім. das Herz zum Schmelzen bringen «ein starkes Gefühl der Liebe erzeugen〉 (RI)‘викликати сильне почуття любові’; укр. тьохкає серие 〈хтось сповнений почуттям кохання〉 (СФУМ: 642).

3.7. Виявом радості, веселощів є сміх, «переривчасті, характерні звуки, які утворюються короткими видихальними рухами як вияв радості, задоволення, нервового збудження і т. ін.> (СУМ, IX: 409). Фразеологізми, які характризують інтенсивний сміх, становлять у досліджуваних мовах значний відсоток вибірки аналізованої ФСПП (35 \%), але найбільше їх у німецькій та українській мовах (50%). У більшості випадків результатом такого інтенсивного фізіологічного вияву радості є деструкція людського організму. На цій підставі виокремлено ММ «сильний сміх - деструкція певної частини людського тіла».

Найчастіше у складі фразеологізмів уживаються соматизми (англ. head 'голова', gut 'кишки, нутрощі'; нім. der Buckel, розм. 'спина', der Bauch 'живіт', der Arsch, груб., лайл. 'зад'; рос. живот (животики), кишки; укр. боки, живіт, кишки), які зазвичай поєднуються 3 дієсловами, що вказують на руйнування об’єкта, пор.: англ. laugh your $\underline{\text { head }}$ off «laugh a lot> (LED)'дуже багато сміятися', букв. 'сміятися так, що аж відпадає голова', bust a gut (laughing) 〈to laugh a lot〉 (360: 168) багато сміятися', букв.

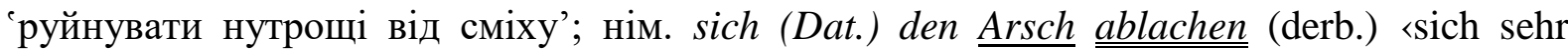
amüsieren, heftig lachen» (Duden: 61)‘дуже веселитися, сильно сміятися’, букв. 'висміяти зад’; рос. надрывать животики / ишки (от смеха), прост. 〈хохотать до изнеможения〉

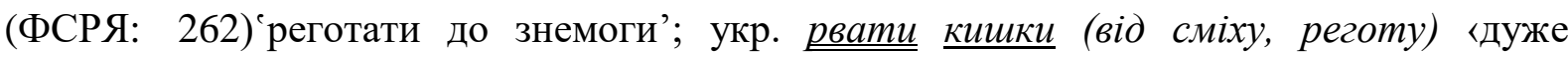
сміятися> (Ужченко: 74).

Сміх як фізичний вияв радості викликає асоціації з фізичним болем, в результаті якого людина може змінювати своє звичайне положення у просторі (згинатися, корчитися, крутитися та ін.) або навіть померти, напр., англ. in stitches laughing very hard (CCID: 340) ‘сміятися дуже сильно’, букв. ‘до кольок’; нім. sich krumm- und schief lachen «über etw. Komisches, Lustiges heftig lachen〉(Duden: 454)‘над чимось комічним, смішним сильно сміятися', букв. 'сміятися вигинаючись та викривляючись'; рос. умирать со смеху 〈неудержимо, до изнеможения смеяться〉 (ФСРЯ: 454) `нестримно, до знемоги сміятися’, укр. аж кольки під грудьмиспирають «сильно сміятися〉 (349, I: 21). 
В англійській та німецькій мовах сила сміху може також вимірюватися через його гучність, що відбилося у таких фразеологізмах, як англ. roar/scream/shriek with laughter «laugh very loudly> (LED) 'сміятися дуже голосно', букв. 'ревти / вищати від сміху, істерично сміятися'; нім. brüllen vor Lachen (Schemann: 458) 'ревіти від сміху', в яких використовуються дієслова звучання (англ. roar/scream/shriek, нім. brüllen), що вказують на дуже голосне продукування звуку.

Серед ФО, що позначають інтенсивний сміх, виокремлюються також і унікальні одиниці. Так, в англійській мові виснажувальна дія голосного сміху передається через образ каналізаційної труби, напр., laugh like a drain «laugh noisily and vigorously» (CCID: 110)'сміятися шумно та енергійно', букв. 'сміятися як дренаж (каналізаційна труба), те, що осушує, виснажує'. В українській мові національно маркованою є одиниця як цицан сироваткою заливатися 〈дуже, сильно (сміятися)〉 (Ужченко: 213), який має затемнену внутрішню форму. В українських казках (народних і літературних, авторських) циган часто виступає головним персонажем («Циган» П. Куліша, «Циган і чоловік», «Хитрий циган», «Циган косарем», «Циган і ведмідь»). У них циган завжди постає хитрим, ласим до легкого заробітку чоловіком. Так, у казці «Циган косарем» розповідається про брехливого цигана, якого господар найняв для косіння трави, а циган з’їв обід і проспав увесь день. На наступний день господар, щоб провчити цигана, хитрістю змусив його увесь день працювати не ївши, а ввечері, коли господиня частувала цигана, спочатку дала йому горілки, трохи борщу і сироватки, якої він випив дуже багато, оскільки був дуже голодний. А вже після сироватки пішли пироги зі сметаною, які він уже не зміг подужати. Тобто у цій ситуації циган дійсно «заливався» сироваткою, намагаючись швидко наїстися, i, можливо, саме це послугувало основою для створення фразеологізму, в якому згодом слово заливатися почало вживатися у переносному значенні ‘голосно, без упину, захлинаючись, сміятися’ (СУМ, ІІІ: 184).

Висновки. Фразеологізми, що позначають інтенсивний вияв позитивного емоційного стану можуть утворюватися за різними метафоричними моделями, універсальними серед яких є такі: «надзвичайно щаслива, радісна людина - тварина / nтах», «сильна радість / захоплення - повітря / небо / верх», проте в їхніх межах у кожній 3 аналізованих мов можуть виявлятися культурно зумовлені компоненти (наприклад, англ. clam 'молюск', нім. Kalb 'теля').

В усіх зіставлюваних мовах наявні ФО, що характеризують сміх як вияв позитивних емоцій суб'єкта. Вони становлять значний відсоток вибірки аналізованої 
ФСПП (35 \%). Найбільше їх у німецькій та українській мовах (по 50 \% відповідно). Ці одиниці будуються за ММ «сильний сміх - деструкиія певної частини людського тіла». На формальному рівні інтенсивність сміху реалізується через використання дієслів деструкції, що вказують на руйнування об'єкта (найчастіше - органів людини). У германських мовах сила сміху може також вимірюватися через його гучність. Перспективою подальших досліджень може слугувати зіставлення зіставлення специфіки виираження інтенсивності позитивних та негативних емоцій у різноструктурних мовах.

\section{СПИСОК ЛІТЕРАТУРИ}

1. Баранов А. Н., ДобровольскийД. О. Аспекты теории фразеологии / А. Н. Баранов, Д. О. Добровольский. - М. : Занк, 2008. -656 с.

2. Бидерманн Г. Энциклопедия символов / Г. Бидерман: Пер. с нем. / Общ. ред. и предисл. Свенцицкой И. С. - М. : Республика, 1996. - 335 с.

3. Вежбицкая А. Семантические универсалии и базисные концепты / А. Вежбицкая. М. : Языки славянской культуры, 2011. - 568 с.

4. Голованивская M. K. Ментальность в зеркале языка. Некоторые базовые концепты в представлении французов и русских / М. К. Голованивская. - М : Языки славянской культуры, 2009. - 376 с. (Язык. Семиотика. Культура).

5. Изард К.Э. Эмоции человека / К.Э. Изард. - М., 1980. - 182 с.

6. Купер Дж. Энциклопедия символов / Дж. Купер. Кн. IV. Серия «Символы». - М. : Ассоциация Духовного Единения «Золотой век», 1995 - 401 с.

7. Экман П. Психология эмоций. Я знаю, что ты чувствуешь / П. Экман. - СПб, 2010. $-182 \mathrm{c}$. 1992.

8. Diller H.J. Emotion and the Linguistics of English // Proceedings, Tübungen: Niemeier,

9. Nöth W. Symmetries and Asymmetries between Positive and Negative Emotion Words // Proceedings, Tübungen: Niemeier, 1992.

10. Schwarz N., Bless H. Happy and mindless, but sad and smart? The impact of affective states on analityc reasoning // Emotion and social judgment / J. P. Forgas (Ed.). - New York : Pergamon Press, 1991. - P. 55-72.

11. Wierzbicka A. Emotional Universals / A. Wierzbicka // Language Design. - 1999. - № 2. - P. 23-69.

12. Wierzbicka A. Emotions Across Languages and Cultures : Diversity and Universality / A. Wierzbicka. Cambridge : Cambridge University Press, 1999. - P. 285-319.

13. Wierzbicka A. The semantic of Emotions: Fear and its Relatives in English / A. Wierzbicka // Australian Journal of Linguistics. - 1990. - V. 10. - № 2. - P. 35-48.

\section{СПИСОК ДЖЕРЕЛ ІЛЮСТРАТИВНОГО МАТЕРІАЛУ}

1. БФСРЯ: Большой фразеологический словарь русского языка. Значение. Употребление. Культурологический комментарий. / Отв. ред. В. Н. Телия. 2-е изд., стер. - М. : АСТ-ПРЕСС КНИГА, 2006. - 784 с.

2. Кунин: Кунин А. В. Большой англо-русский фразеологический словарь // А. В Кунин. (4-е изд., перераб. и доп.). - М. : «Русский язык», 1984. - 944 с.

3. Полевой: Полевой Б. Повесть о настоящем человеке. - К. : Радянська школа, 1983. $272 \mathrm{c}$.

4. СУМ: Словник української мови : в 11 тт. [Електронний ресурс] / АН УРСР. Інститут мовознавства; (за ред. І. К. Білодіда). - К. : Наукова думка, 1970-1980. - Режим доступу: 
http://sum.in.ua

5. СФУМ: Словник фразеологізмів української мови / Уклад. В. М. Білоноженко, I. С. Гнатюк, В. В. Дятчук, Н. М. Неровня, Т. О. Федоренко. - К. : Наук. думка, 2003. - 787 с.

6. Ужченко: Ужченко В. Д., Ужченко Д. В. Фразеологічний словник української мови. К. : Освіта, 1998. -224 с.

7. Федоров: Федоров А. И. Фразеологический словарь русского литературного языка (Текст): около 13000 фразеологических единиц. 3-е изд. - Москва : АСТ : Астрель, 2008. $879 \mathrm{c}$.

8. ФСРЯ: Фразеологический словарь русского языка / Молотков А.И. - М. : Советская энциклопедия, 1968. - $543 \mathrm{c}$.

9. CCID: Collins Cobuild Idioms Dictionary. - Glasgow : Harper Collins Publishers, 2002. $498 \mathrm{p}$.

10. Duden: Duden. Redewendungen. Wörterbuch der deutschen Idiomatik. Band 11. Dudenverlag : Mannheim, Leipzig, Wien, Zürich. - 959 S.

11. LED: Longman Exams Dictionary [Електронний ресурс] - Режим доступу: Longman Exams Dictionary CD-ROM (C) Pearson Education Limited 2006.

12. ODI: Oxford Dictionary of Idioms / (Edited by Judith Siefring). Oxford: Oxford University Press, 2004. - $352 \mathrm{p}$.

13. ODEI: Oxford Dictionary of English Idioms / (Edited by John Ayto). - Oxford : Oxford University Press, 2009. - 607 p.

14. Schemann: Schemann H. Deutsche Idiomatik Wörterbuch der deutschen Redewendungen im Kontext (2. Auflage, mit vollständig überarbeiteter Einführung). - Stuttgart-Dresden : Walter de Gruyter GmbH \& Co. KG, Berlin/Boston, 1993. - 1037 S.

15. RI: Redensarten Index [Електронний ресурс] - Режим доступу: http://www.redensartenindex.de/links/links-redensarten.php 